\title{
Genotype-specific risk factors for Staphylococcus aureus in Swiss dairy herds with an elevated yield-corrected herd somatic cell count
}

\author{
B. Berchtold, ${ }^{* 1}$ M. Bodmer, ${ }^{*}$ B. H. P. van den Borne, $†$ M. Reist, † H. U. Graber, $\ddagger$ A. Steiner, ${ }^{\star}$ R. Boss, $\ddagger$ \\ and F. Wohlfendert \\ ${ }^{*}$ Clinic for Ruminants, Department of Clinical Veterinary Medicine, Vetsuisse-Faculty, University of Berne, 3012 Berne, Switzerland \\ †Veterinary Public Health Institute, University of Berne, Vetsuisse-Faculty, 3097 Liebefeld, Switzerland \\ $\ddagger$ Agroscope Liebefeld-Posieux Research Station ALP, 3003 Berne, Switzerland
}

\section{ABSTRACT}

Bovine mastitis is a frequent problem in Swiss dairy herds. One of the main pathogens causing significant economic loss is Staphylococcus aureus. Various Staph. aureus genotypes with different biological properties have been described. Genotype B (GTB) of Staph. aureus was identified as the most contagious and one of the most prevalent strains in Switzerland. The aim of this study was to identify risk factors associated with the herd-level presence of Staph. aureus GTB and Staph. aureus non-GTB in Swiss dairy herds with an elevated yield-corrected herd somatic cell count (YCHSCC). One hundred dairy herds with a mean YCHSCC between 200,000 and 300,000 cells/mL in 2010 were recruited and each farm was visited once during milking. A standardized protocol investigating demography, mastitis management, cow husbandry, milking system, and milking routine was completed during the visit. A bulk tank milk (BTM) sample was analyzed by realtime PCR for the presence of Staph. aureus GTB to classify the herds into 2 groups: Staph. aureus GTBpositive and Staph. aureus GTB-negative. Moreover, quarter milk samples were aseptically collected for bacteriological culture from cows with a somatic cell count $\geq 150,000$ cells $/ \mathrm{mL}$ on the last test-day before the visit. The culture results allowed us to allocate the Staph. aureus GTB-negative farms to Staph. aureus non-GTB and Staph. aureus-free groups. Multivariable multinomial logistic regression models were built to identify risk factors associated with the herd-level presence of Staph. aureus GTB and Staph. aureus non-GTB. The prevalence of Staph. aureus GTB herds was 16\% (n = 16), whereas that of Staph. aureus non-GTB herds was $38 \%(\mathrm{n}=38)$. Herds that sent lactating cows to seasonal communal pastures had significantly higher odds of being infected with Staph. aureus GTB (odds ratio: 10.2, 95\% CI: 1.9-56.6), compared with herds without

Received November 25, 2013.

Accepted April 7, 2014.

${ }^{1}$ Corresponding author: beat.berchtold@vetsuisse.unibe.ch communal pasturing. Herds that purchased heifers had significantly higher odds of being infected with Staph. aureus GTB (rather than Staph. aureus non-GTB) compared with herds without purchase of heifers. Furthermore, herds that did not use udder ointment as supportive therapy for acute mastitis had significantly higher odds of being infected with Staph. aureus GTB (odds ratio: 8.5, 95\% CI: 1.6-58.4) or Staph. aureus non-GTB (odds ratio: 6.1, 95\% CI: 1.3-27.8) than herds that used udder ointment occasionally or regularly. Herds in which the milker performed unrelated activities during milking had significantly higher odds of being infected with Staph. aureus GTB (rather than Staph. aureus non-GTB) compared with herds in which the milker did not perform unrelated activities at milking. Awareness of 4 potential risk factors identified in this study guides implementation of intervention strategies to improve udder health in both Staph. aureus GTB and Staph. aureus non-GTB herds.

Key words: bulk milk, Staphylococcus aureus genotype B (GTB), risk factor, Switzerland

\section{INTRODUCTION}

Staphylococcus aureus is one of the most important contagious mastitis pathogens in dairy cattle and is associated with large economic losses (Halasa et al., 2007; Hogeveen et al., 2011). The bovine mammary gland represents the most important reservoir of mastitisassociated Staph. aureus (Sears and Carthy, 2003). Additionally, Staph. aureus has been isolated from extramammary sites such as the teat skin, teat orifice, hock skin, housing infrastructure, feedstuffs, skin of milking personnel, insects, nonbovine animals, milking equipment, farm equipment, and bedding material (Fox et al., 2001; Oliver et al., 2005; Piccinini et al., 2009; Anderson et al., 2012).

With the availability of novel molecular methods, several genotypes of Staph. aureus have been identified with different epidemiological and biological properties (such as different virulence and pathogenicity factors for the different strains; Green and Bradley, 2004; 
Barkema et al., 2006; Graber et al., 2009). In Switzerland, Fournier et al. (2008) identified 17 strains of Staph. aureus by ribosomal spacer (RS)-PCR, of which genotypes B (GTB) and C (GTC) were most frequently diagnosed. Further studies showed that Staph. aureus GTB is udder-associated, contagious, and often responsible for herd health problems, as apparent by a high within-herd Staph. aureus prevalence (ranging from 18.2 to $87.5 \%$; Graber et al., 2009), whereas other Staph. aureus genotypes were associated with a low within-herd Staph. aureus prevalence (ranging from 4.0 to 33.3\%; Graber et al., 2009) and rarely caused herd health problems (Fournier et al., 2008; Graber et al., 2009; Michel et al., 2011). Furthermore, Fournier et al. (2008) and Graber et al. (2009) found that Staph. aureus GTB had specific virulence and pathogenicity factors that were different from those of other Staph. aureus genotypes. Staphylococcus aureus GTB is characterized by the presence of the enterotoxin genes sea, sed, and sej, a long x-region of the spa gene, and a GTB-typical SNP within the lukE gene (Fournier et al., 2008; Graber et al., 2009). In contrast, Staph. aureus GTC was positive for $s e c, s e g, s e i$, and tst, whereas all the remaining genotypes were heterogeneous in their virulence gene pattern. The described virulence gene patterns highly correlated with the genotypes obtained by RS-PCR (Fournier et al., 2008) and were then used to develop a novel analytical approach based on realtime quantitative PCR (qPCR) to detect Staph. aureus GTB highly specifically (Boss et al., 2011; Syring et al., 2012).

Although culturing a single bulk tank milk (BTM) sample has a low sensitivity for detection of Staph. aureus (Francoz et al., 2012), bulk tank milk analysis by PCR is a useful alternative tool for monitoring the udder health status of a herd. It is less expensive, allows for more convenient sampling, and requires less time for laboratory analysis compared with bacteriological culture of quarter milk samples (Jayarao and Wolfgang, 2003; Syring et al., 2012). However, in contrast to aseptically collected quarter milk samples, it is only assumed to be a reliable tool for the monitoring of udder-associated pathogens, because BTM is often contaminated with environmental bacteria (Olde Riekerink et al., 2010). Therefore, Boss et al. (2011) developed and evaluated a qPCR assay for the detection of Staph. aureus GTB in BTM as this is assumed to be a contagious pathogen given the high within-herd prevalence reported (Graber et al., 2009).

For effective prevention of IMI, it is important to know the prevalence and distribution of its causative pathogens as well as the pathogen-specific risk factors associated with the disease (Olde Riekerink et al., 2010). Cow-level risk factors for Staph. aureus IMI include overmilking, poor teat-end condition, epidermal wounds, a higher parity, infected rear quarters, and an additional quarter infected with Staph. aureus within the same cow or herd (Romain et al., 2000; Zadoks et al., 2001; Dufour et al., 2012). Not wearing milking gloves, not following any plausible milking order, no fly control, and no dry cow treatment were identified as important herd-level risk factors for IMI caused by Staph. aureus (Erskine et al., 1987; Hutton et al., 1990; Bartlett and Miller, 1993; Moret-Stalder et al., 2009; Dufour et al., 2012). As risk factors differ among mastitis-causing pathogens, they may also differ between different Staph. aureus genotypes displaying different epidemiological properties. However, not much is known about genotype-specific risk factors for Staph. aureus mastitis.

The aim of this study was to identify risk factors associated with the presence of Staph. aureus GTB and Staph. aureus non-GTB in dairy herds with an elevated yield-corrected herd SCC (YCHSCC).

\section{MATERIALS AND METHODS}

\section{Herd Selection}

Yield-corrected herd SCC is defined as the calculated arithmetic average herd SCC of all lactating animals in the herd taking into account their individual milk production (Lievaart et al., 2007). This is more accurate and better reflects the subclinical mastitis situation in a dairy herd than samples taken from the BTM, because the milk of some cows is withheld (e.g., withdrawal after antimicrobial treatment) from the bulk tank. The following procedure was used to select herds with elevated YCHSCC. In a first step, the 3 Swiss breeding associations (Swissherdbook, Zollikofen, Switzerland; Holstein Breeders' Federation, Posieux, Switzerland; and Swiss Brown Cattle Breeders' Federation, Zug, Switzerland) selected farms that fulfilled the following criteria: an average YCHSCC between 200,000 and 300,000 cells/ $\mathrm{mL}$ and a minimum of 12 tested cows for each of the 11 test-days in the year 2010. Herds with fewer than 15 dairy cows, delivering milk from less than $80 \%$ of the cows to the dairy factory, with more than 2 milkings per day, or with seasonal calving, were excluded. Additionally, herds located in the canton of Ticino were excluded for logistic and language reasons. Out of these preselected dairy herds, 1,000 herds were randomly selected following stratification by breed and proportional to the number of members in the different breeding associations (Holstein Breeders' Federation $\mathrm{n}=200$, Swissherdbook n $=400$, Swiss Brown Cattle Breeders' Federation $n=400$ ) and were invited to participate in the study. Of the 140 farms that were willing to 
Table 1. General farm data questionnaire: overview of the data collected before the farm visit

\begin{tabular}{ll}
\hline Topic & Description \\
\hline Basic data & Farm typology, cadastral zone, production standards (e.g., organic farming, integrated production) \\
Rearing, seasonally communal herds & Young-stock rearing system, heifer purchase, seasonally communal dairy herds (e.g., lactating vs. \\
& dry cows, number of herds sending cows to the same communal pasture) \\
Ddder health management & Drying off method (omit milkings vs. abrupt), use of internal teat sealers, housing system of dry \\
& cows (together with lactating cows or separately), management of acute and subclinical mastitis \\
& (e.g., treatment protocol, analysis of milk samples, application of udder ointment), measures taken \\
& following the monthly milk recording (e.g., California Mastitis Test of suspicious cows, culturing of \\
& milk sample), detection of subclinical mastitis regardless of the monthly milk recording \\
\hline
\end{tabular}

participate, 30 farms were additionally excluded either because they had an automatic milking system in place or because their bookkeeping was insufficient. Out of the remaining 110 farms, 100 were randomly selected and visited between September and December 2011 (n $=75)$ or between September and December 2012 (n $=25)$. The selected farms were situated throughout Switzerland.

\section{Collection of Farm Data}

General farm and udder health management data (Table 1) were recorded with the aid of a questionnaire, which was sent to farmers 1 to $2 \mathrm{wk}$ before the farm visit. Farm visits were conducted by 6 trained veterinarians who followed a standardized protocol. Four joint farm visits were performed before the first visit to reduce interobserver variability. During the visit, data about the following main topics were collected: cow husbandry, milking system, milking hygiene, and observations made on the behavior of the milkers before and during milking (Table 2). Moreover, 2 tests described by Spohr et al. (1996) were conducted to assess the performance of the milking system. The original visit protocol and the questionnaire are available upon request.

\section{Collection of Milk Samples}

Three different types of milk samples were collected during the farm visits. First, quarter milk samples were aseptically collected for bacteriological culture following the guidelines of the National Mastitis Council (NMC, 1999) from all cows with an individual composite SCC $\geq 150,000$ cells $/ \mathrm{mL}$ (based on the result of the previous milk recording). Second, a BTM sample containing the milk of at least one milking was collected at the end of the milking process (NMC, 1999). In addition, clean quarter milk samples were collected from all cows not being milked into the bulk tank, because of the withdrawal period during or after an antimicrobial treatment, or because the cows were within the first $8 \mathrm{~d}$ after calving, or for other defined reasons such as cows only milked once a day or a milk yield $<2 \mathrm{~L}$ per milking (Swiss regulation of hygiene in milk production; FDHA, 2005). All milk samples were stored at $4^{\circ} \mathrm{C}$ during transportation and, once in the laboratory, were immediately frozen at $-20^{\circ} \mathrm{C}$ until further processing.

\section{Laboratory Analyses}

Genotyping of Staph. aureus. Genotyping was performed as described by Fournier et al. (2008). In

Table 2. On-farm questionnaire: overview of the data collected during the farm visit

\begin{tabular}{|c|c|}
\hline Topic & Description \\
\hline Cow husbandry & $\begin{array}{l}\text { Housing system (freestall vs. tiestall), bedding type (rubber mats, sawdust, chopped/long straw, chalk, sand, other), } \\
\text { flooring (rubber mats, concrete, slatted floor, other), manure scraping system (manually or mechanically, frequency) }\end{array}$ \\
\hline Milking system & $\begin{array}{l}\text { Type of milking system (parlor vs. bucket milk unit vs. pipeline system), brand of milking system, vacuum pump } \\
\text { (model, location, capacity, age, technical data), pulsator (electronic vs. pneumatic, type of pulse), regulating valve } \\
\text { (cleanliness, and correctness of installation), milking cluster (number on the farm and in use, cleanliness), milk liners } \\
\text { (type of material, frequency of change, cleanliness), annual service of the milking system, cleaning and disinfection of } \\
\text { the milking system, milk filter (cleanliness and frequency of change), cluster disinfection between subsequent cows (yes } \\
\text { or no), type of cluster disinfection between cows (manual, airwash system, backflush system, other), solution used for } \\
\text { cleaning, washing and disinfection of the milking system after milking (water, hot water, disinfection product, other) }\end{array}$ \\
\hline Milking hygiene & $\begin{array}{l}\text { Wearing milking gloves, wearing special clothing, hand washing (before and during milking), number of milkers, } \\
\text { grouping of mastitic and susceptible cows, milking routine (order and implementation of individual steps), correct } \\
\text { adherence and position of the milking unit, overmilking, falling off of milking clusters during milking, behavior of cows } \\
\text { during milking, checking for complete milk out (manual palpation of the udder, udder massage, nothing), postmilking } \\
\text { teat disinfection, other), teat condition score, observation of milk drops on the teat after milking }\end{array}$ \\
\hline Observations & $\begin{array}{l}\text { General and special observations such as milkers washing their hands from time to time or irregular inflow of milk to } \\
\text { the receiver jar, behavior of the cows before and after milking, performing additional work by the milker during milking }\end{array}$ \\
\hline
\end{tabular}


particular, the $16 \mathrm{~S}$ to $23 \mathrm{~S}$ rRNA intergenic spacer region was amplified by RS-PCR. Each reaction contained, in a total volume of $25 \mu \mathrm{L}, 1 \times$ HotStarTaq Master Mix (Qiagen GmbH, Hilden, Germany), $800 \mathrm{nM}$ concentration of each primer (G1 and L1 primer), and $7 \mu \mathrm{L}$ of template DNA. Compared with the original method of Fournier et al. (2008), template preparation was simplified: 1 staphylococcal colony grown overnight on blood agar (bioMérieux, Geneva, Switzerland) was resuspended in $100 \mu \mathrm{L}$ of $10 \mathrm{~m} M$ Tris- $\mathrm{HCl}$ and $10 \mathrm{~m} M$ EDTA (pH 8.5) and incubated at $95^{\circ} \mathrm{C}$ for 10 min. Afterward, the samples were immediately put on ice and diluted 1:100 in $\mathrm{H}_{2} \mathrm{O}$ (= template DNA). The PCR profile was $95^{\circ} \mathrm{C}$ for $15 \mathrm{~min}$, followed by 27 cycles comprising $94^{\circ} \mathrm{C}$ for $1 \mathrm{~min}$, followed by a 2 -min ramp and annealing at $55^{\circ} \mathrm{C}$ for $7 \mathrm{~min}$. After a further 2-min ramp, extension was done at $72^{\circ} \mathrm{C}$ for 2 min. The RS-PCR reaction was terminated by a final extension at $72^{\circ} \mathrm{C}$ for $10 \mathrm{~min}$ followed by cooling to $4^{\circ} \mathrm{C}$. The amplicons were analyzed by using the miniaturized DNA 7500 Lab-Chip electrophoresis system (Agilent Technologies, Santa Clara, CA). This system separates DNA according to size, resulting in a plot of corresponding peaks (electropherogram), which can be evaluated and translated into a pseudo-gel by software (Agilent Technologies). For interpretation of the RSPCR results, 2 patterns were considered different if 2 or more peaks of the electropherogram differed in size.

Milk Processing for $\boldsymbol{q P C R}$. Bulk tank milk samples that did not contain the milk of all lactating cows of the herd were processed as follows: the 4 single-quarter milk samples of each cow not milked in the tank were pooled to a 4-quarter milk sample by adding equal volumes $(500 \mu \mathrm{L})$ of prewarmed milk $\left(37^{\circ} \mathrm{C}\right)$ in the same tube. From these composite milk samples, $500 \mu \mathrm{L}$ was then added to a calculated volume of BTM based on the number of animals being milked into the bulk tank. For example, if 1 cow out of a herd with 20 lactating cows was not milked in the bulk tank, then 19 parts $(500 \mu \mathrm{L}$ each $)$ of the BTM sample and 1 part $(500 \mu \mathrm{L})$ of the composite milk sample were mixed. These pooled BTM samples were then analyzed for the presence of antibiotic residues according to the manufacturer (Delvotest, DSM Food Specialties, Basel, Switzerland).

Milk samples free of antimicrobial residues $(\mathrm{n}=94)$ were first enriched using the staphylococci-specific Chapman medium, containing $75 \mathrm{~g} / \mathrm{L}$ of $\mathrm{NaCl}$ (Merck, Berne, Switzerland), $10 \mathrm{~g} / \mathrm{L}$ of casein peptone (Merck), $10 \mathrm{~g} / \mathrm{L}$ of D-mannitol (Fluka, Buchs, Switzerland), and $1 \mathrm{~g} / \mathrm{L}$ of meat extract (Oxoid AG, Basel, Switzerland). Enrichment was performed by adding $130 \mu \mathrm{L}$ of prewarmed milk to $1,170 \mu \mathrm{L}$ of Chapman medium and incubating at $37^{\circ} \mathrm{C}$ for $18 \mathrm{~h}$ with shaking at $1,000 \mathrm{rpm}$.
After incubation, $400 \mu \mathrm{L}$ of culture was added to 1,200 $\mu \mathrm{L}$ of a solution containing $180 \mu \mathrm{L}$ of Tris- $\mathrm{HCl}(100$ $\mathrm{m} M, \mathrm{pH} 7.8$ ), $300 \mu \mathrm{L}$ of Triton X-100 2\% (Merck), and $150 \mu \mathrm{L}$ of Lactobacillus casei $\left(1.5 \times 10^{9} \mathrm{cfu}\right)$. After centrifugation $\left(18,000 \times g\right.$ for $5 \mathrm{~min}$ at $\left.20^{\circ} \mathrm{C}\right)$, the supernatant was discarded and the pellet resolved in $150 \mu \mathrm{L}$ of $25 \mathrm{~m} M$ Tris- $\mathrm{HCl}$ and $10 \mathrm{mM}$ EDTA (pH 7.2). The samples were incubated at $95^{\circ} \mathrm{C}$ for $10 \mathrm{~min}$ and immediately placed on ice. Afterward, the samples were processed as described by Boss et al. (2011). The resulting samples of nucleic acids were then used as templates for all PCR analyses. If the sample contained antibiotic residues, bacterial preparation was performed directly from milk without an initial enrichment step as described by Boss et al. (2011).

qPCR for Staph. aureus GTB. Real-time quantitative PCR for Staph. aureus GTB detection was performed as described by Boss et al. (2011). In brief, the qPCR monoplex reactions for lukEB, sea, sed, nuc, and canine distemper virus $\mathrm{N}$ gene $(\boldsymbol{C D} \boldsymbol{V N})$ were run in a total volume of $25 \mu \mathrm{L}$ containing $1 \times$ Roche LightCycler 480 Probes Master (Roche Diagnostics AG, Rotkreuz, Switzerland), using the gene-specific appropriate primer and probe concentrations (Graber et al., 2007; Boss et al., 2011). Finally, $3.5 \mu \mathrm{L}$ of template DNA was added to the qPCR mix. Pipetting steps were performed by a CAS Robotics liquid handling system (Corbett Robotics Pty. Ltd., Eight Mile Plains, Australia). The qPCR steps were as follows: initial step of $95^{\circ} \mathrm{C}$ for $10 \mathrm{~min}$, 45 cycles of $95^{\circ} \mathrm{C}$ for $15 \mathrm{~s}$, and $60^{\circ} \mathrm{C}$ for $1 \mathrm{~min}$. The qPCR was carried out in a Rotor-Gene 6000 real-time analyzer (Corbett Life Science, Hombrechtikon, Switzerland) and was run in duplicate for all genes. Results were considered positive if both reactions were positive. If only 1 reaction showed a positive result or the duplicates differed for more than 1.5 cycles, the qPCR was repeated. A reaction was considered negative for all targets analyzed if amplification resulted in a value $<10$ copies/reaction using a standard curve ranging from 10 to $10^{5}$ copies/reaction. In the case of the enriched samples, values larger than $1.21 \times 10^{4}$ copies of the target gene per assay were considered positive, whereas lower copy numbers were considered negative, according to Syring et al. (2012). The qPCR detection of sea and sed was only performed when $\mathrm{qPCR}$ for $l u k E B$ was positive, as all Staph. aureus GTB strains are positive for lukEB, but Staph. aureus non-GTB strains may also carry lukEB (Fournier et al., 2008; Graber et al., 2009; Table 3).

Assay Controls. A milk sample positive for Staph. aureus GTB and a negative milk sample were added as a positive and negative control, respectively, for the enrichment step as well as for the DNA extraction step. Furthermore, positive and no-template controls were 
Table 3. Classification of Staphylococcus aureus genotype B (GTB) positive, Staph. aureus non-GTB, and Staph. aureus negative herds based on real-time quantitative PCR (qPCR) and bacteriological culture

\begin{tabular}{|c|c|c|c|c|c|c|}
\hline \multicolumn{4}{|c|}{ Target gene ${ }^{1}$} & \multicolumn{3}{|c|}{ Herd classification } \\
\hline$n u c$ & $\operatorname{lukEB}$ & sea & sed & qPCR & $\begin{array}{l}\text { Bacteriological } \\
\text { culture }^{2}\end{array}$ & Final \\
\hline+ & + & + & - & Staph. aureus GTB & + & Staph. aureus GTB \\
\hline+ & + & - & + & Staph. aureus GTB & + & Staph. aureus GTB \\
\hline+ & + & - & - & No Staph. aureus GTB & + & Staph. aureus non-GTB \\
\hline
\end{tabular}

${ }^{1} n u c=$ thermonuclease gene; lukEB = point mutation within leucotoxin E gene; sea = Staph. aureus enterotoxin gene A; sed $=$ Staph. aureus enterotoxin gene $\mathrm{D} ;+=$ test positive; $-=$ test negative; $\mathrm{NA}=$ not analyzed when lukEB was negative.

${ }^{2} \mathrm{~A}$ herd was considered Staph. aureus positive when $\geq 1$ milk sample was Staph. aureus positive.

included for all PCR runs. To check for qPCR inhibitors potentially present in nucleic acids, the samples were analyzed by an additional qPCR containing $C D V N$ gene amplicons as an internal control, which is detected by $C D V N$-specific primers and a fluorescent probe (Graber et al., 2007). Negative qPCR results for the target sequences required a positive $C D V N$ qPCR result to exclude the presence of inhibitors.

Bacteriological Culture and Pathogen Identification. The aseptically collected quarter milk samples from cows with a composite $\mathrm{SCC} \geq 150,000$ cells $/ \mathrm{mL}$ were analyzed by the Institute of Food Safety and Hygiene (University of Zurich, Switzerland). Bacteriological culturing and the identification of the pathogen were performed following the guidelines of the NMC (1999).

\section{Herd Classification}

The results of the GTB-qPCR as well as the results from the bacteriological culturing of the aseptically collected quarter milk samples were used to classify the herds according to their Staph. aureus status (Table 3). First, the GTB-qPCR results classified the herds as either Staph. aureus GTB positive or Staph. aureus GTB negative herds. In a next step, the results of the single quarter bacterial culture were used to classify the Staph. aureus GTB-negative herds as either Staph. aureus non-GTB herds or Staph. aureus-negative herds. A herd was defined to be Staph. aureus positive based on bacteriological culturing if at least one single quarter was positive for Staph. aureus within that herd (Table 3).

\section{Statistical Analyses}

Data were stored using Microsoft Access (Microsoft Corp., Redmond, WA) and further analyzed using the NCSS 2007 (Kaysville, UT) statistical software package. Descriptive statistics were generated for each continuous (mean, median, quartiles, minimum, and maximum) and categorical (frequencies) variable. Additionally, continuously measured variables were tested for linearity with the outcome variable. If the relationship was nonlinear, binary or polytomous categorical terms were considered in the regression models (Dohoo et al., 2009). The variables were categorized based on biological plausibility.

All potential risk factors were screened using univariable multinomial logistic regression models for the following 3 herd-level outcomes: presence of Staph aureus GTB, presence of other Staph. aureus genotypes, and absence of Staph. aureus. An overall $P$-value of $\leq 0.10$ was used as a criterion for selecting variables for the multivariable multinomial logistic regression models. Correlations between selected variables were determined using the Spearman rank correlation coefficient; if risk factor pairs showed an absolute correlation $>0.5$, the biologically more meaningful factor was maintained for the multivariable models to avoid collinearity problems. The variable "ratio of number of feeding places relative to the number of cows" was not selected for the multivariable analysis due to semi-complete separation. Backward and forward model selection procedures (with an overall $P$-to-enter or $P$-to-exclude, respectively) were run and the overall $P$-values, as well as odds ratios (OR) with $95 \%$ CI of variables, were recorded. The stepwise selection process was stopped once all covariates were significantly $(P<0.05)$ contributing to the model or were considered to be a confounder. If addition or exclusion of the covariate altered the model estimates by more than 20\% (Dohoo et al., 2009), confounding was considered to be present and the variable was retained in the model. Interaction terms were not evaluated. The variable "study year" (i.e., the year of the farm visit) was initially forced into the final multivariable model to correct for a potential confounding effect. However, because it was neither significantly contributing to the final model nor confounding the 
effect estimates of the other covariates, it was excluded from the final model. The fit of the final multivariable multinomial logistic regression model was assessed using the deviance and Pearson $\chi^{2}$ test in SAS 9.3 (SAS Institute Inc., Cary, NC); both tests showed an overall good fit of the model.

\section{RESULTS}

\section{Herd Characteristics}

In the selected herds, the median size of the agricultural area of the 100 farms was 30.3 ha (range 12.3-146 ha) and the median number of milked cows was 38 animals (range 16-125). The cadastral zone dispersion included 62 farms in the valley zone, 16 farms in the hillside region, 10 farms in the first mountain region, 11 farms in the second mountain region, and 1 farm in the fourth mountain region. The cadastral zone is defined by the climatic situation (especially the duration of the vegetation period), accessibility, and the topographic surface (especially the percentage of hillside locations). Over all farms, the median 305-d milk yield was 7,044 $\mathrm{kg}$ (range 5,458-9,816 kg). Of all farms, the median of the latest recorded YCHSCC analysis before the visit was 228,000 cells/mL (range 44,000-835,000 cells/mL). The median proportion of SCC measurements $\geq 200,000$ cells $/ \mathrm{ml}$ on the last milk recording before the farm visit was $25.0 \%$ (mean $26.9 \%$; range: $5.3-66.7 \%$ ).

\section{Staph. aureus Herd Status}

The between-herd prevalence of Staph. aureus was $54 \%(\mathrm{n}=54)$, which included $16 \%(\mathrm{n}=16)$ Staph. aureus GTB herds and $38 \%(\mathrm{n}=38)$ Staph. aureus non-GTB herds. The remaining $46 \%$ of herds $(\mathrm{n}=46)$ were identified as negative for Staph. aureus.

\section{Genotype-Specific Risk Factors for Staph. aureus}

In total, 319 variables were analyzed. Ten variables with a $P \leq 0.1$ in the univariable analysis were identified (Table 4) and included in the multivariable analysis. The variable "study year" (i.e., the year of the farm visit) was added to the multivariable model to check for a potential confounding effect even though it had a $P$-value of $>0.1$ in the univariable analysis.

Sixteen farms $(16 \%)$ kept $\geq 1$ lactating cow on seasonal communal pasture during the summer months. Of these, 5 farms did not mix their cows with cows from other farms (i.e., closed herds) while cows were on alpine pasture. This resulted in 11 herds (11\%) with at least one cow in another herd during the seasonal communal pasture.

Table 5 shows the results of the final multinomial multivariable logistic regression model. The final multi- nomial logistic regression model adjusted for the following 4 confounders: culturing of milk samples based on test-day SCC (yes vs. no), observation of drops of milk after milking (yes vs. no), duration of milking ( $\leq 120$ min vs. $>120 \mathrm{~min}$ ), and milking out in case of acute mastitis (always or sometimes vs. never).

Herds from which cows were sent to seasonally communal pastures had significantly higher odds (OR 10.2, 95\% CI: 1.9-56.6) of being infected with Staph. aureus GTB compared with herds without communal pasturing. Compared with Staph. aureus non-GTB herds, herds that purchased heifers had significantly higher odds of being infected with Staph. aureus GTB compared with those that did not purchase heifers. The crude (i.e., not corrected for other factors) percentages for herds being infected with Staph. aureus GTB were 63.6 and $20.0 \%$ in Staph. aureus-positive herds with and without heifer purchases, respectively.

Furthermore, herds that never applied udder ointment in case of acute mastitis had significantly higher odds (OR 8.5, 95\% CI: 1.3-58.4) of being infected with Staph. aureus GTB compared with herds where topical application of udder ointment was sometimes or always performed as supportive treatment. We also detected significantly higher odds (OR 6.1, 95\% CI: 1.3-27.8) of herds being infected with Staph. aureus non-GTB compared with being Staph. aureus negative if udder ointment was not used as supportive treatment in case of acute mastitis.

The overall $P$-value $(P=0.025)$ indicated significantly higher odds of being infected with Staph. aureus GTB compared with Staph. aureus non-GTB in those herds in which the milker performed unrelated activities during milking. Unrelated activities were defined as activities performed in addition and simultaneously to milking, such as feeding the calves, cleaning the barn, or answering a phone call. The crude percentages of Staph. aureus GTB infection were 40.0 and $25.6 \%$ in Staph. aureus-positive herds where milkers performed and did not perform unrelated tasks (e.g., such as cleaning or feeding the calves) during milking, respectively.

\section{DISCUSSION}

The aim of this study was to identify risk factors associated with the presence of Staph. aureus GTB and Staph. aureus non-GTB in Swiss dairy herds with an elevated YCMSCC. The study identified 4 risk factors related to different aspects of mastitis management.

\section{Seasonally Communal Dairy Herds}

In some Swiss mountain regions, heifers and lactating cows are kept on communal pastures during summer. 
Table 4. Overview of the variables with a $P$-value $<0.1$ in the univariable analysis (including study year) of Staphylococcus aureus genotype B (GTB), Staph. aureus non-GTB, and Staph. aureus-negative herds

\begin{tabular}{|c|c|c|c|}
\hline Factor and category & $\begin{array}{c}\text { Staph. aureus GTB } \\
(\mathrm{n}=16)\end{array}$ & $\begin{array}{c}\text { Staph. aureus } \\
\text { non-GTB }(\mathrm{n}=38)\end{array}$ & $\begin{array}{c}\text { Non-Staph. aureus } \\
(\mathrm{n}=46)\end{array}$ \\
\hline \multicolumn{4}{|c|}{ Seasonally communal dairy herds, no. (\%) } \\
\hline Yes & $8(8)$ & $3(3)$ & $5(5)$ \\
\hline \multicolumn{4}{|c|}{ Culturing of milk samples based on test day SCC, no. (\%) } \\
\hline Yes & $4(4)$ & $6(6)$ & $17(17)$ \\
\hline Sometimes or no & $12(12)$ & $32(32)$ & $29(29)$ \\
\hline$>120 \min$ & $4(4)$ & $2(2)$ & $1(1)$ \\
\hline \multicolumn{4}{|c|}{ Observation of milk drops after milking, no. (\%) } \\
\hline Yes & $9(9)$ & $6(6)$ & $11(11)$ \\
\hline No & $7(7)$ & $32(32)$ & $35(35)$ \\
\hline \multicolumn{4}{|c|}{ Application of udder ointment in case of acute mastitis, no. (\%) } \\
\hline Âlways or sometimes & $10(10)$ & $29(29)$ & $43(43)$ \\
\hline Never & $6(6)$ & $9(9)$ & $3(3)$ \\
\hline No & $9(9)$ & $34(34)$ & $35(35)$ \\
\hline \multicolumn{4}{|c|}{ Unrelated activities during milking time, no. (\%) } \\
\hline Yes & $10(10)$ & $11(11)$ & $19(19)$ \\
\hline No & $6(6)$ & $27(27)$ & $27(27)$ \\
\hline \multicolumn{4}{|c|}{ Duration of dry period, no. (\%) } \\
\hline$\leq 8 \mathrm{wk}$ & $4(4)$ & $23(23)$ & $24(24)$ \\
\hline$>8 \mathrm{wk}$ & $12(12)$ & $15(15)$ & $22(22)$ \\
\hline \multicolumn{4}{|c|}{ Ratio of number of feeding places to number of cows } \\
\hline $1: 1$ & $12(12)$ & $33(33)$ & $45(45)$ \\
\hline$>1: 1$ & $4(4)$ & $5(5)$ & $1(1)$ \\
\hline \multicolumn{4}{|l|}{ Study year, no. (\%) } \\
\hline 2011 & $12(12)$ & $31(31)$ & $32(32)$ \\
\hline 2012 & $4(4)$ & $7(7)$ & $14(14)$ \\
\hline
\end{tabular}

During this period, animals from different herds of origin are usually mixed and share milking equipment (V. Voelk, Clinic for Ruminants, Berne, Switzerland, personal communication) Biosecurity measures for seasonally communal dairy herds differ from region to region, and their implementation into daily routine tends to be limited. In 2006, approximately 120,000 $(22 \%)$ of the 550,000 lactating cows in Switzerland spent the summer on a seasonally communal pasture (Swiss Federal Office of Statistics; http://www.bfs.ad-

Table 5. Overview of the significant variables in the final multivariable multinomial logistic regression model associated with the presence of Staphylococcus aureus genotype B (GTB) versus non-Staph. aureus and Staph. aureus non-GTB versus non-Staph. aureus

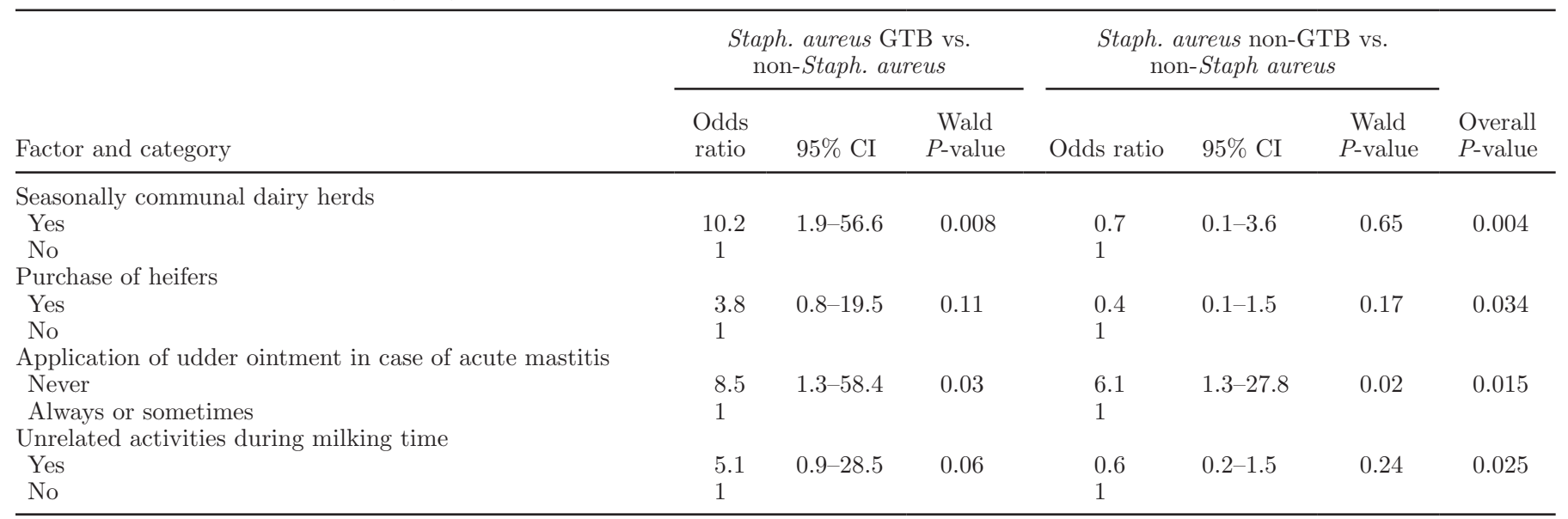


min.ch/bfs/portal/en/index.html), which is a slightly higher percentage than described in our study. Communal pasturing of lactating cows during summer was a significant herd-level risk factor for the presence of Staph. aureus GTB in the BTM. Cattle movements, as well as mixing cows with unknown infection status from different herds and milking them with the same milking equipment, increase the risk of Staph. aureus spread between dairy herds (Green and Bradley, 2004; Kristula et al., 2009; V. Voelk, Clinic for Ruminants, Berne, Switzerland, personal communication).

\section{Heifer Purchase}

Despite the fact that nonlactating heifers have not yet been in contact with the milking equipment, they may still be infected with Staph. aureus (Fox, 2009). Therefore, the purchase of Staph. aureus-positive heifers represents a risk for the introduction and spread of Staph. aureus within the herd when they start lactating. Piepers et al. (2011) identified "missed fly control" as a significant risk factor for heifer mastitis caused by contagious mastitis pathogens such as Staph. aureus and Streptococcus agalactiae. Because the majority of heifers in Switzerland are pastured during summer, often in groups from different herds of origin and housed with the dry cows during the rest of the year, flies might be a vector for IMI caused by Staph. aureus in periparturient heifers (Nickerson et al., 1995; Zadoks et al., 2001; Capurro et al., 2010). Further work is needed to understand the exact transmission of IMI caused by Staph. aureus to periparturient heifers (De Vliegher et al., 2012). Although recommendations to control heifer mastitis are currently not part of the National Mastitis Council's prevention program, recent evidence suggests that they should be included (De Vliegher et al., 2012). In particular, if heifers are purchased from herds with unknown Staph. aureus status, IMI status should be evaluated thoroughly after calving before introducing them into the group with lactating animals.

\section{Application of Udder Ointment in Case of Acute Mastitis}

In addition to antimicrobial treatment, application of udder ointment as a supportive treatment in case of acute, as well as chronic subclinical, mastitis is common practice in Switzerland. The treatments are defined as a topical application of an ointment to the skin of the mammary gland to trigger a hyperemia. The majority of the products contain camphor, methylsalicylate, or both, as active substances. Two separate reasons may explain the association between the absence of Staph. aureus GTB and Staph. aureus non-GTB in the BTM and the application of udder ointments. First, farmers who routinely apply udder ointment in the presence of signs of mastitis may be more aware of pathological changes in the mammary gland, triggering early intervention with intramammary antimicrobials. Second, application of ointment in case of acute mastitis increases blood circulation, which, in turn, may support the immune system by providing more immune cells, thereby inhibiting internalization of Staph. aureus (Rainard and Riollet, 2003; Wellnitz and Bruckmaier, 2012). However, both explanations remain speculative, and further research is needed to evaluate the association of udder ointment application and the presence of Staph. aureus genotypes in the BTM.

\section{Unrelated Activities During Milking}

The steps of a correct milking routine have been well described (NMC, 1999). If the steps are performed as suggested, limited time is left for additional tasks during milking. However, given the excessive workload on many farms, farmers tend to optimize the workflow by executing tasks unrelated to milking, such as cleaning the cubicles or feeding the cows, while milking. The farmer not being present in the milking parlor might increase the risk of overmilking, which might, in turn, result in a higher risk of IMI with Staph. aureus (Capurro et al., 2010). This may explain the higher odds of Staph. aureus GTB infection in herds where the milker performed unrelated tasks during milking.

The mean size of the agricultural area in the current study was slightly higher compared with the mean size reported by the Swiss milk producers (TSM Treuhand GmbH, Berne, Switzerland; www.swissmilk.ch). Also, the 305-d milk yield, at $6,204 \mathrm{~kg} / \mathrm{cow}$ (TSM Treuhand $\mathrm{GmbH}$ ), was slightly lower than the $7,044 \mathrm{~kg} /$ cow in our study. The difference in both factors may be explained by the fact that valley farms were slightly overrepresented in our study compared with the number reported by the milk producer organization (TSM Treuhand GmbH). Gordon et al. (2013) published a median yearly proportion of milk samples with a composite SCC $\geq 200,000$ cells $/ \mathrm{mL}$ of $16.1 \%$ (mean $17.3 \%$ ) in a random sample of Swiss dairy herds. This is lower than in our study population, in which herds with udder health problems were selected to participate. However, full comparison between the 2 studies is not possible. A yearly proportion was reported by Gordon et al. (2013), whereas a proportion of elevated SCC measurements at the testday before the last visit was determined in the current study. Seasonal changes in SCC are commonly observed and they bias a true comparison between the 2 studies.

This study showed a higher between-herd prevalence of Staph. aureus (54\%) than unpublished data collected 
in the context of the study of Moret-Stalder et al. (2009) (38\%; T. Kaufmann, Rindergesundheitsdienst, Lindau, Switzerland, personal communication). The differences are most likely caused by different selection criteria of the study herds. Herd selection for the present study was based on elevated YCHSCC, whereas a randomly selected sample of dairy herds in the canton of Berne (Switzerland) was investigated in the study of MoretStalder et al. (2009). It is known that farms with a high YCHSCC are more likely to have cows suffering from clinical and subclinical IMI caused by Staph. aureus (Hutton et al., 1990; Barkema et al., 1998). The prevalence of Staph. aureus GTB herds was 16\% $(\mathrm{n}=16)$ in the present study, which is higher than the herd-level prevalence of Staph. aureus GTB of $10.3 \%$ observed in a random selection of Swiss dairy herds in the year 2012 (23 out of 223 herds were Staph. aureus GTB positive; H. U. Graber, unpublished data). However, this difference was not significant $(P=0.15)$, implying that the 2 study populations are comparable for their Staph. aureus GTB status.

Risk factors for Staph. aureus are well described by different authors and may be divided into cow-level and herd-level risk factors (e.g., Dufour et al., 2012). Besides the fact that Staph. aureus genotypes were investigated, rather than the entire species, another possible reason why we found different risk factors for Staph. aureus in our study may be the fact that Switzerland has an extensive amount of animal movement (e.g., communal pasturing, expositions, and auctions) without any specific biosecurity measures being in place to limit the spread of Staph. aureus. This characteristic of the Swiss dairy industry may explain more of the variation in Staph. aureus occurrence than the on-farm management practices usually identified.

With the qPCR analysis of the BTM samples, herds were categorized as being either Staph. aureus GTBpositive or Staph. aureus GTB-negative. As described by Syring et al. (2012), the risk of misclassifying a herd with regards to Staph. aureus GTB is limited by the fact that the qPCR has a high diagnostic sensitivity and specificity. To allocate the Staph. aureus GTBnegative herds to Staph. aureus non-GTB and Staph. aureus-negative groups, we cultured aseptically collected quarter milk samples from cows with elevated composite SCC. All Staph. aureus GTB-positive herds were also positive for Staph. aureus by bacteriological culture, and all Staph. aureus negative herds were negative by bacteriological culture. Presence of the Staph. aureus-specific nuc gene, as determined by qPCR in the current study, could have been used to discriminate Staph. aureus GTB-negative herds into Staph. aureus non-GTB and Staph. aureus-negative herds. However, several authors have shown that certain Staph. aureus strains are present in the immediate environment of the cow and, therefore, are potential contaminants of the BTM (Roberson et al., 1994; Capurro et al., 2010; Francoz et al., 2012). These environmental Staph. aureus strains are also detected with the current qPCR analysis, which could have resulted in false-positive $n u c$ test results. By detecting Staph. aureus in aseptically collected milk samples from individual cows, the potential risk of misclassifying herds caused by contamination of BTM was reduced. Nevertheless, the risk of misclassification of herds cannot be fully excluded because only cows with composite $\mathrm{SCC} \geq 150,000$ cells $/ \mathrm{mL}$ were eligible for aseptic sampling. Shedding of Staph. aureus from infected mammary glands may be cyclic, resulting in a lower diagnostic sensitivity if only high-SCC cows are sampled (Sears et al., 1990; Studer et al., 2008). The effect of the latter is assumed to be minor, however, as all cows with a composite SCC $\geq 150,000$ cells $/ \mathrm{mL}$ were sampled, and the herd was defined to be positive for Staph. aureus if at least one quarter was positive by culture.

Collecting data over a long period may be influenced by bias over time. Statistically, we found no difference between the results of farms visited in 2011 and 2012 . Moreover, we can exclude a seasonal influence because all farms were visited in autumn (2011: $\mathrm{n}=75 ; 2012$ : $\mathrm{n}=25$ ); therefore, results from both years could be pooled for statistical analysis.

We are aware of a potential confounding effect caused by having 6 veterinarians perform the on-farm observations, which could have resulted in misclassification bias of the data collected. This, however, was minimized by providing training for the personnel, including 4 joint farm visits performed before the study, where interpretation of the visit protocol was discussed. The influence of the 6 veterinarians on risk factor classification could not be evaluated, because not every veterinarian visited at least one Staph. aureus GTB-positive herd.

With the current study design, causal relationships between risk factors and outcomes could not be assessed. Furthermore, the number of visited herds and the inclusion of problem herds may have had a negative effect on the representativeness of the presented study. Risk factors for Staph. aureus are well described, but the identification of genotype-specific risk factors for Staph. aureus has been missing until now.

\section{CONCLUSIONS}

This study described 4 manageable risk factors associated with the presence of Staph. aureus genotypes in the bulk milk of herds with an elevated SCC. The identified risk factors included sending cows to seasonally communal dairy herds, purchase of heifers, no applica- 
tion of udder ointment in case of acute mastitis, and performing unrelated activities during milking. The identification of these herd-level risk factors guides the implementation of strategies to improve udder health in Staph. aureus GTB and Staph. aureus non-GTB herds.

\section{ACKNOWLEDGMENTS}

The study was supported by the "Spezialisierungskommission" of the Vetsuisse Faculty, University Berne (Berne, Switzerland). We thank the breeding organizations for the logistic support and Lydia Kretzschmar, Daniela Heiniger (Clinic for Ruminants, Department of Clinical Veterinary Medicine, Vetsuisse-Faculty, University of Berne, Switzerland), Aurélie Tschopp, and Myriam Harisberger (Veterinary Public Health Institute, Vetsuisse-Faculty, University of Berne, Switzerland) for their assistance in collecting the data.

\section{REFERENCES}

Anderson, K. L., R. Lyman, K. Moury, D. Ray, D. W. Watson, and M. T. Correa. 2012. Molecular epidemiology of Staphylococcus aureus mastitis in dairy heifers. J. Dairy Sci. 95:4921-4930.

Barkema, H. W., Y. H. Schukken, T. J. G. M. Lam, M. L. Beiboer, G. Benedictus, and A. Brand. 1998. Management practices associated with low, medium, and high somatic cell counts in bulk milk. J. Dairy Sci. 81:1917-1927.

Barkema, H. W., Y. H. Schukken, and R. N. Zadoks. 2006. Invited review: The role of cow, pathogen, and treatment regimen in the therapeutic success of bovine Staphylococcus aureus mastitis. J. Dairy Sci. 89:1877-1895.

Bartlett, P. C., and G. Y. Miller. 1993. Managerial risk factors for intramammary coagulase-positive staphylococci in Ohio dairy herds. Prev. Vet. Med. 17:33-40.

Boss, R., J. Naskova, A. Steiner, and H. U. Graber. 2011. Mastitis diagnosis: Quantitative PCR for Staphylococcus aureus genotype B in bulk tank milk. J. Dairy Sci. 94:128-137.

Capurro, A., A. Aspán, H. Ericsson Unnerstad, K. Persson Waller, and K. Artursson. 2010. Identification of potential sources of Staphylococcus aureus in herds with mastitis problems. J. Dairy Sci. 93:180-191.

De Vliegher, S., L. K. Fox, S. Piepers, S. Mc Dougall, and H. W. Barkema. 2012. Invited review: Mastitis in dairy heifers: Nature of the disease, potential impact, prevention, and control. 2012. J. Dairy Sci. 95:1025-1040.

Dohoo, R. I., S. W. Martin, and H. Stryhn. 2009. Veterinary Epidemiologic Research. 2nd ed. VER, Inc, Charlottetown, Prince Edward Island, Canada.

Dufour, S., I. R. Dohoo, H. W. Barkema, L. DesCôteaux, T. J. DeVries, K. K. Reyher, J. P. Roy, and D. T. Scholl. 2012. Manageable risk factors associated with the lactational incidence, elimination, and prevalence of Staphylococcus aureus intramammary infections in dairy cows. J. Dairy Sci. 95:1283-1300.

Erskine, R. J., R. J. Eberhart, L. J. Hutchinson, and S. B. Spencer. 1987. Herd management and prevalence of mastitis in dairy herds with high and low somatic cell counts. J. Am. Vet. Med. Assoc. 190:1411-1416.

Fournier, C., P. Kuhnert, J. Frey, R. Miserez, M. Kirchhofer, T. Kaufmann, A. Steiner, and H. U. Graber. 2008. Bovine Staphylococcus aureus: Association of virulence genes, genotypes and clinical outcome. Res. Vet. Sci. 85:439-448.

Fox, L. K. 2009. Prevalence, incidence and risk factors of heifer mastitis. Vet. Microbiol. 134:82-88.
Fox, L. K., K. W. Bayles, and G. A. Bohach. 2001. Staphylococcus aureus mastitis. Pages 271-294 in Staphylococcus aureus Infection and Disease. A. L. Honeyman, H. Friedman, and M. Bendinelli, ed. Kluwer Academic/Plenum Publishers, New York, NY.

Francoz, D., L. Bergeron, M. Nadeau, and G. Beauchamp. 2012. Prevalence of contagious mastitis pathogens in bulk tank milk in Québec. Can. Vet. J. 53:1071-1078.

Gordon, P. F., B. H. P. van den Borne, M. Reist, S. Kohler, and M. Doherr. 2013. Questionnaire-based study to assess the association between management practices and mastitis within tie-stall and free-stall dairy housing systems in Switzerland. BMC Vet. Res. 9:200.

Graber, H. U., M. G. Casey, J. Naskova, A. Steiner, and W. Schaeren. 2007. Development of a highly sensitive and specific assay to detect Staphylococcus aureus in bovine mastitic milk. J. Dairy Sci. 90:4661-4669.

Graber, H. U., J. Naskova, E. Studer, T. Kaufmann, M. Kirchhofer, M. Brechbühl, W. Schaeren, A. Steiner, and C. Fournier. 2009. Mastitis-related subtypes of bovine Staphylococcus aureus are characterized by different clinical properties. J. Dairy Sci. 92:1442-1451.

Green, M., and A. Bradley. 2004. Clinical Forum-Staphylococcus aureus mastitis in cattle. Cattle Pract. 9:1-9.

Halasa, T., K. Huijps, O. Østerås, and H. Hogeveen. 2007. Economic effects of bovine mastitis and mastitis management: A review. Vet. Q. 29:18-31.

Hogeveen, H., K. Huijps, and T. Lam. 2011. Economic aspects of mastitis: New developments. N. Z. Vet. J. 59:16-23.

Hutton, C. T., L. K. Fox, and D. D. Hancock. 1990. Mastitis control practices: Differences between herds with high and low milk somatic cell counts. J. Dairy Sci. 73:1135-1143.

Jayarao, B. M., and D. R. Wolfgang. 2003. Bulk-tank milk analysis: A useful tool for improving milk quality and herd udder health. Vet. Clin. North Am. Food Anim. Pract. 19:75-92.

Kristula, M. A., M. E. Fecteau, B. I. Smith, S. Young, and S. C. Rankin. 2009. Evaluation of the risk of transmitting Staphylococcus aureus strains between replacement heifers through commingling at a heifer-rearing facility. Bovine Pract. 43:75-83.

Lievaart, J. J., W. D. J. Kremer, and H. W. Barkema. 2007. Short communication: Comparison of bulk milk, yield-corrected, and average somatic cell counts as parameters to summarize the subclinical mastitis situation in a dairy herd. J. Dairy Sci. 90:4145-4148.

Michel, A., C. Syring, A. Steiner, and H. U. Graber. 2011. Intramammary infections with the contagious Staphylococcus aureus genotype B in Swiss dairy cows are associated with low prevalence of coagulase-negative staphylococci and Streptococcus spp. Vet. J. 188:313-317.

Moret-Stalder, S., C. Fournier, R. Miserez, S. Albini, M. G. Doherr, M. Reist, W. Schaeren, M. Kirchhofer, H. U. Graber, A. Steiner, and T. Kaufmann. 2009. Prevalence study of Staphylococcus aureus in quarter milk samples of dairy cows in the Canton of Bern, Switzerland. Prev. Vet. Med. 88:72-76.

Nickerson, S. C., W. E. Owens, and R. L. Boddie. 1995. Mastitis in dairy heifers: Initial studies on prevalence and control. J. Dairy Sci. $78: 1607-1618$.

NMC (National Mastitis Council). 1999. Laboratory Handbook on Bovine Mastitis. Rev. ed. National Mastitis Council Inc., Madison, WI.

Olde Riekerink, R. G., H. W. Barkema, D. T. Scholl, D. E. Poole, and D. F. Kelton. 2010. 7. Management practices associated with the bulk-milk prevalence of Staphylococcus aureus in Canadian dairy farms. Prev. Vet. Med. 97:20-28.

Oliver, S. P., B. E. Gillespie, S. J. Headrick, M. J. Lewis, and H. H. Dowlen. 2005. Prevalence, risk factors, and strategies for controlling mastitis in heifers during the periparturient period. Int. J. Appl. Res. Vet. Med. 3:150-162.

Piccinini, R., L. Cesaris, V. Daprà, V. Borromeo, C. Picozzi, C. Secchi, and A. Zecconi. 2009. The role of teat skin contamination in the epidemiology of Staphylococcus aureus intramammary infections. J. Dairy Res. 76:36-41.

Piepers, S., K. Peeters, G. Opsomer, H. W. Barkema, K. Frankena, and S. de Vliegher. 2011. Pathogen group specific risk factors at 
herd, heifer and quarter levels for intramammary infections in early lactating dairy heifers. Prev. Vet. Med. 99:91-101.

Rainard, P., and C. Riollet. 2003. Mobilization of neutrophils and defense of the bovine mammary gland. Reprod. Nutr. Dev. 43:439 457.

Roberson, J. R., L. K. Fox, D. D. Hancock, J. M. Gay, and T. E Besser. 1994. Ecology of Staphylococcus aureus isolated from various sites on dairy farms. J. Dairy Sci. 77:3354-3364.

Romain, H. T., A. A. Adesiyun, L. A. Webb, and F. B. Lauckner. 2000. Study on risk factors and their association with subclinical mastitis in lactating dairy cows in Trinidad. J. Vet. Med. B Infect. Dis. Vet. Public Health 47:257-271.

Sears, P. M., and K. K. Carthy. 2003. Management and treatment of staphylococcal mastitis. Vet. Clin. North Am. Food Anim. Pract. 19:171-185.

Sears, P. M., B. S. Smith, P. B. English, P. S. Herer, and R. N. Gonzalez. 1990. Shedding pattern of Staphylococcus aureus from bovine intramammary infections. J. Dairy Sci. 72:1900-1906.

Spohr, M., K. Wolf, and A. Hesslinger. 1996. Beurteilung der Melktechnik durch den praktischen Tierarzt. Prakt. Tierarzt 77:635638.
Studer, E., W. Schaeren, J. Naskova, H. Pfaeffli, T. Kaufmann, M. Kirchhofer, A. Steiner, and H. U. Graber. 2008. A longitudinal field study to evaluate the diagnostic properties of a quantitative real-time polymerase chain reaction-based assay to detect Staphylococcus aureus in milk. J. Dairy Sci. 91:1893-1902.

Syring, C., R. Boss, M. Reist, M. Bodmer, J. Hummerjohann, P. Gehrig, and H. U. Graber. 2012. Bovine mastitis: The diagnostic properties of a PCR-based assay to monitor the Staphylococcus aureus genotype B status of a herd, using bulk tank milk. J. Dairy Sci. 95:3674-3682.

FDHA (Federal Department of Home Affairs). 2005. Verordnung des EDI über die Hygiene bei der Milchproduktion. VHyMP, 5.916.351.021.1.

Wellnitz, O., and R. Bruckmaier. 2012. The innate immune response of the bovine mammary gland to bacterial infection. Vet. J. 192:148-152.

Zadoks, R. N., H. G. Allore, H. W. Barkema, O. C. Sampimon, G. J. Wellenberg, Y. T. Grohn, and Y. H. Schukken. 2001. Cow- and quarter-level risk factors for Streptococcus uberis and Staphylococcus aureus mastitis. J. Dairy Sci. 84:2649-2663. 